\title{
Ultra-processed food consumption and obesity in adolescents
}

\section{Consumo de alimentos ultraprocessados e obesidade em adolescentes}

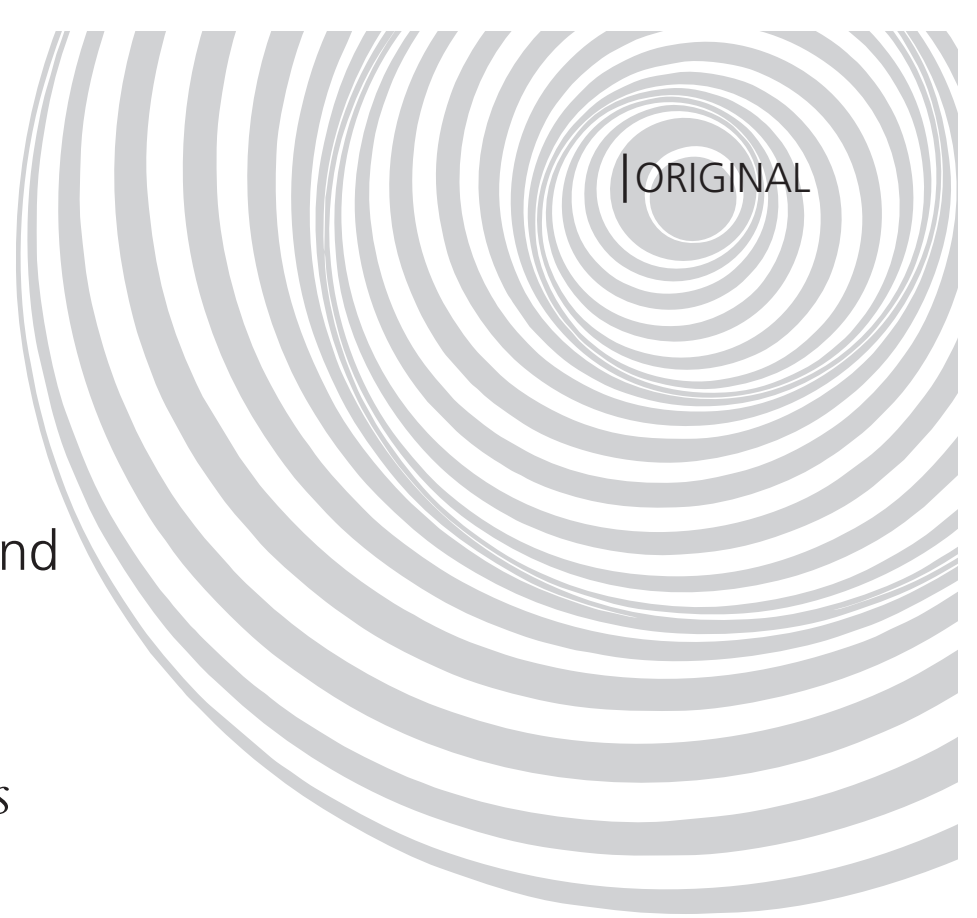

\author{
Carla Cristina ENES ${ }^{1}$ iD 0000-0002-4634-4402 \\ Carolina Moura de CAMARGO2 (D) 0000-0001-7947-3385 \\ Maraisa Isabela Coelho JUSTINO1 (iD) 0000-0002-0963-1381
}

A B S T R A C T

\section{Objective}

To evaluate the relationship between ultra-processed food consumption and obesity indicators in adolescents.

\section{Methods}

Cross-sectional study with a convenience sample of 200 10- to 18-year-old adolescents from Campinas, São Paulo (SP). Usual dietary intake was determined through a semiquantitative food frequency questionnaire. Daily intake of each food was obtained from the intake frequency. Subsequently, foods were classified as raw and minimally processed, cooking ingredients or ultra-processed foods, and their caloric contribution to the total energy value was calculated. Sociodemographic and anthropometric variables were also investigated. Overweight was defined as Z-score >+1 and obesity was defined as Z-score >+2 according to the Body Mass Index per age group. The associations were tested by chi-square test and linear trend.

\section{Results}

The frequency of obesity was $47.0 \%$, and $21.5 \%$ presented increased waist circumference. The average energy intake was $4,176 \mathrm{kcal} / \mathrm{day}$, of which $50.6 \%$ was derived from ultra-processed foods. The categories with the highest caloric contributions among ultra-processed foods were industrial loaves/cakes (16.2\%), sweets and candy $(6.2 \%)$, pastas $(6.0 \%)$ and sweetened drinks (5.1\%). No association was found between ultra-processed food consumption and anthropometric indicators.

\footnotetext{
1 Pontifícia Universidade Católica de Campinas, Centro de Ciências da Vida, Programa de Pós-Graduação em Ciências da Saúde. Av. John Boyd Dunlop, s/n., Prédio Administrativo, Jd. Ipaussurama, 13060-904, Campinas, SP, Brasil. Correspondence to: CC ENES. E-mail: <cacenes@gmail.com>.

2 Pontifícia Universidade Católica de Campinas, Centro de Ciências da Vida, Faculdade de Nutrição. Campinas, SP, Brasil.
}

\footnotetext{
How to cite this article

Enes CC, Camargo CM, Justino MIC. Ultra-processed food consumption and obesity in adolescents. Rev Nutr. 2019;32:e18170. http://dx.doi.org/10.1590/1678-9865201932e180170
} 


\section{Conclusion}

The significant contribution of ultra-processed foods to daily calories is evidence of a poor diet of this population of young people, although this has not been shown as a factor associated with excess weight. Therefore, there is an urgent need for public policies that discourage the consumption of these products and encourage the return to a traditional diet.

Keywords: Adolescents. Food. Nutrition. Obesity. Risk factor.

\section{RE S U M O}

\section{Objetivo}

Avaliar a relação entre o consumo de alimentos ultraprocessados e indicadores de obesidade em adolescentes.

\section{Métodos}

Estudo transversal com amostra de conveniência de 200 adolescentes de 10 a 18 anos, de Campinas (SP). O consumo alimentar habitual foi obtido por meio de um questionário de frequência alimentar semiquantitativo. A partir da frequência de consumo foi obtido o consumo diário de cada alimento. Posteriormente os alimentos foram classificados em in natura e minimamente processados, ingredientes culinários e alimentos ultraprocessados e calculada sua contribuição calórica no valor energético total. Variáveis sociodemográficas e antropométricas também foram investigadas. O sobrepeso foi definido por meio do escore Z>1 e a obesidade escore Z>2 segundo o Índice de Massa Corporal para idade. As associações foram testadas pelo teste quiquadrado e de tendência linear.

\section{Resultados}

A frequência de obesidade foi de $47,0 \%$ e 21,5\% apresentaram circunferência da cintura aumentada. 0 consumo médio de energia foi de $4.176 \mathrm{kcal} / \mathrm{dia}$, sendo $50,6 \%$ provenientes de ultraprocessados. As categorias com as maiores contribuições calóricas entre os ultraprocessados foram os pães/bolos industrializados (16,2\%), doces e guloseimas $(6,2 \%)$, massas $(6,0 \%)$ e bebidas adoçadas $(5,1 \%)$. Não observou-se associação entre o consumo de ultraprocessados e indicadores antropométricos.

\section{Conclusão}

A expressiva contribuição dos ultraprocessados nas calorias diárias evidencia a qualidade ruim da alimentação dos jovens, embora não tenha se mostrado como fator associado ao excesso de peso. Ressalta-se a necessidade urgente de políticas públicas que desestimulem o consumo destes produtos e incentivem o resgate da alimentação tradicional.

Palavras-chave: Adolescentes. Alimento. Nutrição. Obesidade. Fator de risco.

\section{NTRODUCTION}

Overweight and obesity have reached disturbing levels in Brazil in recent years. Among adolescents, overweight affects one in three young people according to the latest Family Budget Survey 2008-9 [1]

The increase in obesity in the population has occurred in parallel with changes in the global food system, which currently makes available a wide variety of ready-to-eat foods and beverages, known as ultra-processed foods. These foods are often low in fiber and protein, and high in sodium, fats and sugars [2,3]. In addition, their high palatability, which is associated with their convenience and aggressive advertising, are factors that have stimulated their consumption [3].

In Brazil, a study in a representative sample of adolescents and adults revealed a positive association between ultra-processed food and beverage consumption and obesity [4]. Similar results were found in a study in an adult American population [5]. In Latin America, research performed in 15 countries revealed an association between the purchase of ultra-processed foods and weight gain in 12 countries [6]. 
Prospective cohort studies also identified an association between the consumption of ultra-processed foods and dyslipidemia [7], hypertension [8] and cancer [9].

Recently, a prospective study conducted in adults in France revealed that an increase in ultra-processed food consumption was associated with an increased risk of overall mortality among this population [10].

Considering the finding discussed above and that most published studies prioritize adult populations, the objective of this study was to evaluate the relationship between ultra-processed food consumption and obesity indicators in adolescents.

\section{METHODS}

\section{Population and study location}

This was a cross-sectional study performed in 10- to 18-year-old adolescents of both sexes who attended a Non-Governmental Organization (NGO) in the city of Campinas (SP). This NGO aims to develop activities with children, adolescents and families and helps prevent social risk and violation of rights scenarios, which promotes the integral development and strength of family and community ties.

A population of 526 10- to 18-year-old adolescents registered for this project was considered in the sample size calculation, considering its three units (Unit I=171, Unit $I=205$ and Unit $I I=150$ ). A $21 \%$ prevalence of excess weight was found in a study with a similar population to this one [11], and a Type I error of 5\% and a Type II error of 10\% were considered, which amounts to a minimum sample of 172 adolescents as representative of the study population. Considering the possible losses due to refusal to participate in the study, the consent form was given to all adolescents attending $(\mathrm{N}=526)$, and only 210 adolescents returned the form signed by their parents/guardians. However, 10 adolescents were not found in the units on the days of data collection and therefore did not participate in the study, which resulted in a final sample of 200 adolescents. This study was approved by the ethics committee of the Pontifícia Unviersidade Católica de Campinas (PUC-Campinas, Pontifical Catholic University of Campinas) under the opinion No.1,130.649.

\section{Food intake}

Usual food intake was evaluated by a semiquantitative Simplified Food Frequency Questionnaire for Adolescents (SFFQA) validated for energy and nutrients [12]. The SFFQA comprises 58 foods with their average portions and evaluates intake in the last three months. This tool has seven frequency categories that range from never to two or more times/day. The portions presented in the SFFQA represent the average intake, in grams, of each food. Daily intake frequency and the daily intake of each food in grams (daily frequency $x$ average portion of the food in grams) were calculated from the frequency reported for each food. Daily calories from each food were obtained by multiplying the daily amount consumed (in grams) by the average portion of calories (previously known), divided by the average portion (in grams). The caloric contribution of each of the studied groups was determined according to the sum of the calories of each food that composed the group. The daily Total Energy Intake (TEI) was obtained from the sum of the calories of each consumed food. Total calorie values $<500 \mathrm{kcal}$ and $\geq 7500 \mathrm{kcal} /$ day were considered outliers. 


\section{Food classification according to the degree of processing}

The 58 foods were divided into three main groups based on the four groups proposed by the NOVA classification, which considers processing extent and purpose [13]. The first group consisted of "raw and minimally processed foods", which are those that have not undergone any changes since they were extracted from nature (raw) or those that have undergone processes such as those for the removal of inedible or undesirable parts of the food, drying, grinding or milling and pasteurization, among others (minimally processed). The second category was "processed cooking ingredients", which includes substances extracted directly from foods from the first group or nature and consumed as cooking ingredients. The third group consisted of "ultra-processed foods", which includes industrial formulations typically composed of five or more ingredients; these include substances and additives used in the manufacture of processed foods such as sugar, oils, fats and salt, as well as antioxidants, stabilizers and preservatives. In the SFFQA used, no food item could be classified in the category "processed foods" as proposed by NOVA.

For each group, the caloric contribution (\%) was calculated in relation to the daily TEI.

\section{Indicators of nutritional status}

Weight was measured using a Balmak ${ }^{\circledR}$ (Santa Barbara d'Oeste, Brazil) portable electronic scale with a precision of $50 \mathrm{~g}$, and height was measured using an Alturexata ${ }^{\circledR}$ (São Paulo, Brazil) stadiometer with a precision of $1 \mathrm{~mm}$. Anthropometric measurements were performed by trained researchers using standardized techniques [14]. Waist Circumference (WC) was taken at the waist line at the midpoint between the last rib and the iliac crest using a TBW $^{\circledR}$ (São Paulo, Brazil) inelastic tape measure.

Adolescents' nutritional status was classified according to the World Health Organization BMI using age reference curves [15]. The following were the cutoff points used for classification: Z-score $\geq-2$ and Z-score $\leq+1$ for normal weight; Z-score $>+1$ and Z-score $\leq+2$ for overweight; and Z-score $>+2$ for obesity.

Abdominal obesity was evaluated by the Waist-to-Hip Ratio (WHR). The criteria recommended by Li et al. [16] was used to assess the WHR, and a value $\geq 0.5$ was used as the cutoff point to define abdominal obesity. All anthropometric measures were duplicated using the mean value.

\section{Covariates: Sex, age, race, economic condition and physical activity}

Information on age, sex, race/ethnicity, socioeconomic condition and physical activity was obtained during interviews. The socioeconomic classification was based on the Associação Brasileira de Empresas de Pesquisas (Brazilian Survey Companies Association) criteria [17], which accounts for the presence and quantity of household items such as TV, radios, washing machines, computers, cars, and number of bathrooms, among others, and the education level of the head of the family. This instrument allows the classification of the population into classes A1, A2, B1, B2, C1, C2, D and E, in descending order of purchasing power.

Regular physical activity was assessed by a validated questionnaire for adolescents [18] that includes physical activities during leisure time in the last 12 months. The average weekly time (in minutes) that some physical activity was performed was calculated from this information. Adolescents were classified as "under-active" or "active" based on the weekly 300-minutes cutoff established by the United Kingdom Expert Consensus Group [19]. 


\section{Statistical analysis}

Descriptive statistics (Means and Standard Error) were calculated and the frequencies were estimated for the main anthropometric and consumption indicators. Chi-square and linear trend tests were used to evaluate the association between ultra-processed food consumption quartiles (\% of TEI) and socio-demographic variables and anthropometric indicators. ANOVA was used to evaluate the differences in Body Mass Index (BMI) by quartiles of ultra-processed food consumption. Statistical analyses were performed using Stata (Stata Corporation, College Station, Texas, United States) version 12.0, and the level of significance was set at $5 \%$.

\section{RES U L T S}

Most adolescents (56.0\%) were female, 10 to 14 years of age (88.5\%), self-declared brown (42.0\%) and belonged to class C2 (46.2\%) (Table 1). Almost half of the adolescents (47.0\%) were obese, and $21.5 \%$ presented with cardiovascular risk and increased waist circumference. Physical activity was insufficient in more than $90.0 \%$ of the interviewees.

Table 1. Characteristics of the adolescents interviewed. Campinas (SP), Brazil, 2016.

\begin{tabular}{|c|c|c|}
\hline Variables & $\mathrm{N}$ & $\%$ \\
\hline \multicolumn{3}{|l|}{ Sex } \\
\hline Male & 88 & 44.0 \\
\hline Female & 112 & 56.0 \\
\hline \multicolumn{3}{|l|}{ Age (years) } \\
\hline $10-14$ & 177 & 88.5 \\
\hline $15-18$ & 23 & 11.5 \\
\hline \multicolumn{3}{|l|}{ Race/ethnicity } \\
\hline White & 44 & 22.0 \\
\hline Black & 57 & 28.5 \\
\hline Brown & 84 & 42.0 \\
\hline Other & 15 & 7.5 \\
\hline \multicolumn{3}{|l|}{ Economic stratum } \\
\hline D-E & 53 & 26.6 \\
\hline C2 & 92 & 46.2 \\
\hline C1-B2 & 54 & 27.1 \\
\hline \multicolumn{3}{|l|}{ Nutritional status } \\
\hline Normal weight & 71 & 35.5 \\
\hline Overweight & 35 & 17.5 \\
\hline Obese & 94 & 47.0 \\
\hline \multicolumn{3}{|l|}{ Abdominal obesity } \\
\hline No & 157 & 78.5 \\
\hline Yes & 43 & 21.5 \\
\hline \multicolumn{3}{|c|}{ Leisure physical activity in min/week } \\
\hline Insufficiently active & 187 & 93.5 \\
\hline Active & 13 & 6.5 \\
\hline
\end{tabular}


The average energy intake was 4,176kcal/day, and ultra-processed food consumption contributed $50.6 \%$ of the total calories consumed, while minimally processed foods accounted for $46.7 \%$ (Table 2). On average, grains (rice and corn) and beans accounted for more than 1/4 of the calories eaten. Fruits (5.6\%) and milk (4.0\%) also had a substantial contribution to the minimally processed foods group. Among ultra-processed foods, the categories with the highest caloric contributions were industrial breads (16.2\%), sweets and candies $(6.2 \%)$, pasta $(6.0 \%)$ and sweetened beverages (5.1\%) (Table 2).

The contribution of ultra-processed foods to the total ingested calories averaged $32.9 \%$ in the first quartile and $68.3 \%$ in the last quartile (data not shown in the table).

Table 2. Food caloric contribution in daily total energy intake according to the degree of processing. Campinas (SP), Brazil, 2016.

\begin{tabular}{|c|c|c|c|c|}
\hline \multirow{2}{*}{ Food groups and subgroups } & \multicolumn{2}{|c|}{ Absolute ingestion (kcal/day) } & \multicolumn{2}{|c|}{ Relative intake (\% total kcal) } \\
\hline & Mean & (SE) & Mean & $(\mathrm{SE})$ \\
\hline Group 1: Raw and minimally processed foods & 1803.4 & $(680.5)$ & 46.7 & $(1.0)$ \\
\hline Milk & 157.2 & $(9.2)$ & 4.0 & $(0.3)$ \\
\hline Fruits & 235.7 & $(15.4)$ & 5.6 & $(0.3)$ \\
\hline Vegetables and greens & 17.2 & $(1.4)$ & 0.4 & $(0.0)$ \\
\hline Beans & 476.6 & $(19.1)$ & 12.9 & $(0.5)$ \\
\hline Grains (rice and corn) & 521.9 & $(13.1)$ & 14.6 & $(0.5)$ \\
\hline Roots/tubers & 72.9 & (7.5) & 1.5 & $(0.1)$ \\
\hline White meat & 141.2 & $(13.6)$ & 3.2 & $(0.3)$ \\
\hline Red meat & 125.4 & $(12.5)$ & 3.2 & $(0.3)$ \\
\hline Eggs & 55.1 & $(5.0)$ & 1.3 & $(0.1)$ \\
\hline Group 2: Processed Cooking Ingredients & 103.8 & (90.8) & 2.7 & $(0.2)$ \\
\hline Sugar & 71.6 & $(5.6)$ & 1.8 & $(0.1)$ \\
\hline Vegetable oil & 32.2 & $(2.4)$ & 0.8 & $(0.1)$ \\
\hline Group 3: Ultra-processed foods & 2268.8 & (1443.3) & 50.6 & $(1.0)$ \\
\hline Breads/cookies/cake & 703.2 & $(34.1)$ & 16.2 & $(0.6)$ \\
\hline Sweets and candies & 290.1 & $(20.7)$ & 6.2 & $(0.3)$ \\
\hline Soft drinks/sweetened industrial drinks & 215.2 & $(12.3)$ & 5.1 & $(0.3)$ \\
\hline Sausages & 148.2 & $(11.2)$ & 3.2 & $(0.2)$ \\
\hline Fast food snacks ${ }^{a}$ & 165.4 & $(16.4)$ & 3.4 & $(0.2)$ \\
\hline Industrial snacks ${ }^{\mathbf{b}}$ & 81.6 & $(11.0)$ & 1.8 & $(0.2)$ \\
\hline Fried, salted and stuffed baked goods & 178.2 & $(20.1)$ & 3.7 & $(0.3)$ \\
\hline Pastas & 280.8 & $(25.5)$ & 6.0 & $(0.4)$ \\
\hline Creams and sauces $^{c}$ & 111.6 & $(7.3)$ & 2.8 & $(0.2)$ \\
\hline Cheeses $^{d}$ & 22.0 & (3.3) & 0.5 & $(0.1)$ \\
\hline Cottage cheese/processed yogurt & 72.3 & $(6.5)$ & 1.7 & $(0.1)$ \\
\hline
\end{tabular}

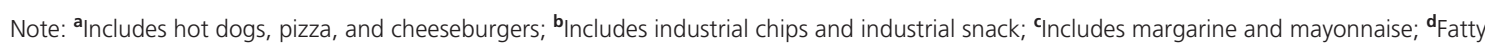
cheeses.

SE: Standard Error. 
When analyzing the relationship among socio-demographic variables, anthropometric indicators and physical activity and the contribution of ultra-processed foods to total caloric intake by quartiles, only socioeconomic status showed a positive and significant association with ultra-processed food consumption (Table 3).

Table 3. Characteristics of adolescents by quartiles of caloric contribution of ultra-processed foods to daily total energy intake. Campinas (SP), Brazil, 2016.

\begin{tabular}{|c|c|c|c|c|c|c|c|c|c|}
\hline \multirow{3}{*}{ Variables } & \multicolumn{9}{|c|}{ Quartiles of ultra-processed food intake } \\
\hline & \multicolumn{2}{|c|}{$1^{\text {st }}$ quartile } & \multicolumn{2}{|c|}{$2^{\text {nd }}$ quartile } & \multicolumn{2}{|c|}{$3^{\text {rd }}$ quartile } & \multicolumn{2}{|c|}{$4^{\text {th }}$ quartile } & \multirow{2}{*}{$p$-value } \\
\hline & M & $(\mathrm{SE})$ & M & $(\mathrm{SE})$ & M & $(\mathrm{SE})$ & M & $(\mathrm{SE})$ & \\
\hline Sex & & & & & & & & & $0.474^{*}$ \\
\hline Male & 33.4 & $(1.3)$ & 45.4 & (0.6) & 55.7 & $(0.4)$ & 67.1 & (1.4) & \\
\hline Female & 32.5 & $(1.4)$ & 45.6 & $(0.7)$ & 55.5 & $(0.5)$ & 69.0 & $(1.1)$ & \\
\hline Age (years) & & & & & & & & & $0.757^{* *}$ \\
\hline $10-14$ & 33.5 & $(0.9)$ & 45.6 & $(0.5)$ & 55.5 & $(0.4)$ & 68.6 & $(1.0)$ & \\
\hline $15-18$ & 28.6 & (3.9) & 44.1 & (2.0) & 56.2 & $(1.1)$ & 66.6 & (1.1) & \\
\hline Race & & & & & & & & & $0.077^{*}$ \\
\hline White & 34.4 & (2.4) & 47.2 & (1.1) & 56.1 & $(0.6)$ & 68.2 & (1.9) & \\
\hline Black & 31.5 & $(2.2)$ & 44.4 & $(0.6)$ & 55.2 & $(0.6)$ & 72.3 & $(2.7)$ & \\
\hline Brown & 32.8 & $(1.1)$ & 45.5 & $(0.7)$ & 55.4 & $(0.7)$ & 66.6 & $(0.8)$ & \\
\hline Others & 35.3 & (2.3) & 45.6 & (3.6) & 55.5 & $(0.8)$ & 70.2 & (3.7) & \\
\hline Economic stratum & & & & & & & & & $0.023^{* *}$ \\
\hline$D-E$ & 32.8 & $(1.7)$ & 45.7 & $(1.1)$ & 56.0 & $(0.8)$ & 63.4 & $(0.8)$ & \\
\hline C2 & 32.8 & $(1.2)$ & 45.3 & $(0.5)$ & 56.0 & $(0.5)$ & 68.6 & $(1.3)$ & \\
\hline C1-B2 & 32.7 & $(4.1)$ & 45.6 & $(0.9)$ & 54.6 & $(0.6)$ & 70.8 & (1.4) & \\
\hline Nutritional status & & & & & & & & & $0.383^{* *}$ \\
\hline Normal weight & 32.5 & (1.6) & 46.0 & $(0.7)$ & 55.8 & $(0.5)$ & 68.9 & (1.9) & \\
\hline Overweight & 33.0 & $(2.1)$ & 45.5 & $(0.8)$ & 55.7 & $(1.1)$ & 68.3 & (1.4) & \\
\hline Obese & 33.1 & (1.3) & 44.7 & $(0.8)$ & 55.4 & $(0.5)$ & 67.8 & $(1.0)$ & \\
\hline Abdominal obesity & & & & & & & & & $0.122^{*}$ \\
\hline Without risk & 33.2 & $(1.1)$ & 45.8 & $(0.5)$ & 55.7 & $(0.4)$ & 68.3 & $(1.1)$ & \\
\hline At risk & 32.3 & $(1.9)$ & 43.4 & $(1.4)$ & 54.9 & $(0.5)$ & 68.5 & $(1.1)$ & \\
\hline Leisure physical activity (min/week) & & & & & & & & & $0.526^{*}$ \\
\hline Insufficiently active & 36.2 & $(4.1)$ & 45.9 & $(1.8)$ & 56.7 & $(1.3)$ & 68.6 & $(5.7)$ & \\
\hline Active & 32.8 & $(1.0)$ & 45.4 & $(0.5)$ & 55.5 & $(0.3)$ & 68.3 & $(0.9)$ & \\
\hline
\end{tabular}

Note: ${ }^{*}$ Chi-square test; ${ }^{* *}$ Linear trend test.

M: Mean; SE: Standard Error.

Although no significant association was found between the contribution of ultra-processed foods in the diet and anthropometric indicators and the mean BMI was not significantly different for the different intake quartiles, a higher prevalence of overweight, obesity and abdominal obesity was observed in the first quartile (Table 4). 
Table 4. Obesity indicators according to quartiles of the contribution of ultra-processed foods to the daily caloric intake of adolescents. Campinas (SP), Brazil, 2016.

\begin{tabular}{|c|c|c|c|c|c|}
\hline \multirow{2}{*}{$\begin{array}{l}\text { Quartiles of ultra-processed foods intake } \\
\text { (\% total energy) }\end{array}$} & \multicolumn{2}{|c|}{$\mathrm{BMI}^{\mathrm{a}}$} & \multirow{2}{*}{ Overweight (\%) ${ }^{\mathbf{b}}$} & \multirow{2}{*}{ Obesity $(\%)^{\mathbf{b}}$} & \multirow{2}{*}{ Abdominal obesity $(\%)^{b}$} \\
\hline & Mean & SD & & & \\
\hline $1^{\text {st }}$ quartile $(13.3 \%-40.4 \%)$ & 21.9 & $(5.65)$ & 28.1 & 33.3 & 38.5 \\
\hline $2^{\text {nd }}$ quartile (40.9\%-51.1\%) & 19.4 & $(4.71)$ & 22.3 & 16.1 & 15.4 \\
\hline $3^{\text {rd }}$ quartile (51.2\%-60.0\%) & 20.4 & $(4.35)$ & 25.6 & 25.3 & 20.5 \\
\hline $4^{\text {th }}$ quartile $(60.5 \%-86.3 \%)$ & 19.9 & $(3.82)$ & 24.0 & 25.3 & 25.6 \\
\hline
\end{tabular}

Note: ${ }^{\mathrm{a} A N O V A}, p>0.05$; ${ }^{\mathbf{b}}$ Linear trend test, $p>0.05$.

BMI: Body Mass Index; SD: Standard Deviation.

\section{DISCUSSION}

Ultra-processed foods accounted for the largest portion of food consumed by adolescents, and a larger share was contributed by processed breads, cakes and sweets, pasta and sweetened beverages. Higher consumption of these foods in the higher income classes was observed. Although no significant association was found between ultra-processed food consumption and obesity, a high prevalence of excess weight (overweight+obese) was observed in adolescents.

Ultra-processed foods are typically prepared with refined ingredients, fats, salt and sugars with high energy density, high glycemic load and high palatability. These foods also contain large amounts of chemical additives and have low protein and fiber content. In addition, because they are marketed frequently and aggressively, they may influence the development of eating habits [20].

According to the Pan American Health Organization (PAHO) and World Cancer Research Fund International, ultra-processed foods - especially sweetened beverages, fast food and snacks with high energy density -, are the main factors related to obesity, diabetes, cardiovascular diseases and various cancers [6]. A population study conducted in Canada also showed that diets that contain large quantities of these foods do not meet the recommendations of the World Health Organization (WHO) and others for the prevention and control of obesity and chronic non-transmissible diseases [3].

In Brazil, the last National School Health Survey in 2015 [21] revealed an increased consumption of ultra-processed foods, such as sausages, cookies, biscuits and soft drinks and a decreased consumption of raw and minimally processed foods such as fruits, vegetables, beans and milk; these behaviors contribute to weight gain, metabolic changes and micronutrient deficiency $[21,22]$.

The higher contribution of ultra-processed foods (50.6\%) to total calories found in the present study is in agreement with the findings of other national and international studies, both in adult populations and in younger populations [23]. In a survey performed in a municipality in southern Brazil, ultra-processed foods contributed $49.0 \%$ of the total calories ingested by adolescents [24]. Similar results were found in Canada (51.2\%) [3], the United States (57.9\%) [25] and the United Kingdom (50.4\%) [26], where diets also contained predominantly ultra-processed foods.

The lack of an association between ultra-processed food consumption and obesity in adolescents observed in the present study is different from other studies that also investigated the same relationship [4-6,24]. A study of a representative sample of Brazilian adolescents and adults [4] identified a relationship between ultra-processed food consumption and obesity. It is likely that the findings of the present study were divergent due to the limited sample type and size. 
Another notable result is the high prevalence of obesity (47.0\%) found among adolescents, which was higher than in other studies with similar populations. A population survey conducted in the same municipality in the interior of São Paulo showed that $35.0 \%$ of students were overweight, while $12.0 \%$ were obese [27]. A meta-analysis involving 21 studies and a sample of 18,463 Brazilian children and adolescents found a prevalence of obesity of $14.1 \%$ [28].

This discrepancy in the prevalence of obesity compared with other studies may be related to the unique characteristics of the studied sample. Other research has shown an association between low socioeconomic status and increased risk of obesity $[29,30]$. This is probably due to the presence of food insecurity and food choices in low-income households, in which foods of low nutritional value and high energy density are predominant.

In the present study, higher income was associated with a higher contribution of ultraprocessed foods in the diets of adolescents, which contradicts the evidence presented in other studies and reveals a negative association between income and the contribution of ultra-processed foods to the diet [24,31]. It is possible that such a discrepancy is due to the homogeneity of the studied sample, which consists predominantly of low-income youth.

Food choices are known to be determined not only by physiological needs but also by the influence of environmental factors such as food quality, availability, accessibility, convenience, advertising and price. In this context, the replacement of raw and minimally processed foods by ultra-processed foods becomes widely favored. With regard to price, raw or minimally processed foods such as milk, meat, vegetables and fruits tend to be more expensive than ultra-processed foods produced by industry on a large scale. Thus, purchasing food that is considered healthy is more frequent in families with higher incomes than in families with lower purchasing power [32].

According to PAHO surveys in 2013 [6], in countries that sell less ultra-processed food and where traditional food is still prevalent, as in Peru and Bolivia, the average BMI of the population is lower, whereas in countries that sell more ultra-processed food, as in Chile and Mexico, the BMI tends to be higher.

Ultra-processed foods can be considered the main vectors for sugar, salt and fats in the diet. Their production, commercialization and aggressive advertising are subject to setbacks from regulatory actions aimed at the food industry. Likewise, production incentives and greater accessibility to healthy foods should be the target of public policies that include support and protection of family farming [6].

One limitation of this study is the sample size of 200 adolescents, which may have contributed to the statistical non-association between ultra-processed consumption and obesity due to the low power of the statistical test. The tool used to evaluate food intake (SFFQA) and the interviewee's memory bias may also have contributed to an overestimation of consumption because the SFFQA evaluated food consumption during the three months preceding the survey. Finally, as this is a convenience sample, where a specific population has been included, the results should be interpreted with caution.

\section{CONCLUSION}

The substantial contribution of ultra-processed foods to total calories shows the poor quality of young people's diets, although this poor quality has not been shown to be associated with overweight and obesity. Most adolescents showed excess weight, and ultra-processed food 
consumption was higher among those from families with a higher income. Considering these results, the urgent need for public policies that discourage the consumption of these products and intervene in their production, commercialization and advertising may be warranted. On the contrary, establishing policies that incentivize and promote a return to traditional diets is fundamental.

\section{CONTRIBUTORS}

CC ENES participated in the design of the study, analysis and interpretation of data, review and final approval of the manuscript. CM CAMARGO participated in the collection and interpretation of data, writing, review and final approval of the manuscript. MIC JUSTINO participated in the collection and interpretation of data, revision and final approval of the manuscript.

\section{REFERENCES}

1. Instituto Brasileiro de Geografia e Estatística. Pesquisa de Orçamentos Familiares 2008-2009: antropometria e estado nutricional de crianças, adolescentes e adultos no Brasil. Rio de Janeiro: IBGE; 2010.

2. Louzada MLC, Ricardo CZ, Steele EM, Levy RB, Cannon G, Monteiro CA. The share of ultra-processed foods determines the overall nutritional quality of diets in Brazil. Public Health Nutr. 2018;21(1):94-102. http:// dx.doi.org/10.1017/S1368980017001434

3. Moubarac JC, Martins AP, Claro RM, Levy RB, Cannon G, Monteiro C. Consumption of ultra-processed foods and likely impact on human health: Evidence from Canada. Public Health Nutr. 2013;16(12):2240-8.

4. Louzada MLC, Baraldi LG, Martinez E, Martins APB, Canella DS, Moubarac J, et al. Consumption of ultra-processed foods and obesity in Brazilian adolescents and adults. Prev Med. 2015;81:9-15.

5. Juul F, Martinez-Steele E, Parekh N, Monteiro CA, Chang VW. Ultra-processed food consumption and excess weight among US adults. Br J Nutr. 2018;120(1):90-100.

6. Pan American Health Organization. Ultra-processed food and drink products in Latin America: Trends, impact on obesity, policy implications. Washington (DC): PAHO; 2013.

7. Rauber F, Campagnolo PD, Hoffman DJ, Vitolo MR. Consumption of ultra-processed food products and its effects on children's lipid profiles: A longitudinal study. Nutr Metab Cardiovasc Dis. 2015;25(1):116-22. http://dx.doi.org/10.1016/j.numecd.2014.08.001

8. Mendonça RD, Lopes ACS, Pimenta AM, Gea A, Martinez-Gonzalez MA, Bes-Rastrollo M. Ultra-processed food consumption and the incidence of hypertension in a Mediterranean cohort: The Seguimiento Universidad de Navarra Project. Am J Hypertens. 2017;30(4):358-66.

9. Fiolet T, Srour B, Sellem L, Kesse-Guyot E, Allès B, Méjean C, et al. Consumption of ultra-processed foods and cancer risk: Results from NutriNet-Sante prospective cohort. BMJ. 2018;360:k322.

10. Schnabel L, Kesse-Guyot E, Alles B, Touvier M, Srour B, Hercberg S, et al. Association between ultraprocessed food consumption and risk of mortality among middle-aged adults in France. JAMA Intern Med. 2019;179(4):E1-9. http://dx.doi.org/10.1001/jamainternmed.2018.7289

11. Toral N, Slater B, Silva MV. Consumo alimentar e excesso de peso de adolescentes de Piracicaba, São Paulo. Rev Nutr. 2007;20(5):449-59. http://dx.doi.org/10.1590/S1415-52732007000500001

12. Slater B, Philippi ST, Fisberg RM, Latorre MRDO. Validation of a semi-quantitative adolescent food frequency questionnaire applied at a public school in São Paulo, Brazil. Eur J Clin Nutr. 2003;57(5):629-35.

13. Monteiro CA, Cannon G, Moubarac J, Levy RB, Louzada MLC, Jaime PC. The UN Decade of Nutrition, the NOVA food classification and the trouble with ultra-processing. Public Health Nutr. 2017:21(1):51-7.

14. Lohman TG, Roche AF, Martorell R. Anthropometric standardization reference manual. Champaign: Human Kinetics Books, 1988.

15. Onis M, Onyango AW, Borghi E, Siyam A, Nishida C, Siekmann J. Development of a WHO growth reference for school-aged children and adolescents. Bull World Health Org. 2007;85(9):660-7. 
16. Li C, Ford ES, Mokdad AH, Cook S. Recent trends in waist circumference and waist-height ratio among US children and adolescents. Pediatrics. 2006;118(5):1390-98.

17. Associação Brasileira de Empresas de Pesquisa. Critério Brasil 2015 e atualização da distribuição de classes para 2016. ABEP; 2016 [citado 2017 nov 20]. Disponível em: www.abep.org/Servicos/Download. aspx?id=09

18. Florindo AA, Romero A, Peres SV, Silva MV, Slater B. Development and validation of a physical activity assessment questionnaire for adolescents. Rev Saúde Pública. 2006;40(5):802-9.

19. Pate RR, Freedson PS, Sallis JF, Taylor WC, Sirard J, Trost SG, et al. Compliance with physical activity guidelines: Prevalence in a population of children and youth. Ann Epidemiol. 2002;12(5):303-8.

20. Machado PP, Claro RM, Canella DS, Sarti FM, Levy RB. Price and convenience: The influence of supermarkets on consumption of ultra-processed foods and beverages in Brazil. Appetite. 2017;116:381-8.

21. Instituto Brasileiro de Geografia e Estatística. Pesquisa nacional de saúde do escolar. Rio de Janeiro: IBGE; 2015.

22. Souza AM, Barufaldi LA, Abreu GA, Giannini DT, Oliveira CL, Santos MM, et al. ERICA: ingestão de macro e micronutrientes em adolescentes brasileiros. Rev Saúde Pública. 2016;50Supl1:1-5. http://dx.doi. org/10.1590/S01518-8787.2016050006698

23. Bielemann RM, Motta JVS, Minten GC, Horta BL, Gigante DP. Consumo de alimentos ultraprocessados e impacto na dieta de adultos jovens. Rev Saúde Pública. 2015;49:28.

24. D’Avila HF, Kirsten VR. Consumo energético proveniente de alimentos ultraprocessados por adolescentes. Rev Paul Pediatr. 2017;35(1):54-60.

25. Steele EM, Baraldi LG, Louzana MLC, Moubarac JC, Mozaffarian D, Mointeiro CA. Ultra-processed foods and added sugars in the US diet: Evidence from a nationally representative cross-sectional study. BMJ Open. 2016;6(3):e009892.

26. Monteiro CA, Moubarac JC, Levy RB, Canella DS, Louzana MLC, Cannon G. Household availability of ultra-processed foods and obesity in nineteen European coutries. Public Health Nutr. 2017;21(1):18-26.

27. Castilho SD, Nucci LB, Hansen LO, Assuino SR. Prevalencia del exceso de peso conforme a la franja de edad en alumnos de escuelas de Campinas, São Paulo. Rev Paul Pediatr. 2014;32(2):200-6.

28. Aiello AM, Mello LM, Nunes MS, Silva AS, Nunes A. Prevalence of obesity in children and adolescents in Brazil: A meta-analysis of cross-sectional studies. Curr Pediatr Rev. 2015;11(1):36-42.

29. Kaur J, Lamb MM, Ogden CL. The association between food insecurity and obesity in children: The national health and nutrition examination survey. J Acad Nutr Diet. 2015;115(5):751-8.

30. Salmasi L, Celidoni M. Investigating the poverty-obesity paradox in Europe. Econ Hum Biol. 2017;26:70-85.

31. Baker P, Friel S. Processed foods and the nutrition transition: Evidence from Asia. Obes Rev. 2014;15(7):564-77.

32. Claro RM, Mata EG, Costa BVL, Diniz DP. Preço dos alimentos no Brasil: prefira preparações culinárias a alimentos ultraprocessados. Cad Saúde Pública. 2016;32(8):e00104715. 